\title{
A Survey on Instructional Leadership Framework (ILF) Status at Margarito A. Duavit Memorial and Vicente Madrigal National High Schools
}

\author{
Rolando Ramos Onilongo ${ }^{1 *}$ \\ 1. Graduate School, Emilio Aguinaldo College, San Marcelino St., Paco, Manila 1007, Philippines \\ * E-mail of the corresponding author: rronilongo.mnl@eac.edu.ph
}

\begin{abstract}
Educational leadership defines how well an educational institution performs. It encompasses the ability to adapt to best practices and implement it seamlessly. Being a leader in an educational setting requires one to take some degree of risk to innovate new system that is expected to bring the institution to a higher status of efficiency in service delivery. This study aimed to explore the leadership status of instructional leadership among high school administrators and schoolteacher in two government national high schools using the adopted Instructional Leadership Framework instrument. Based on the survey and exploratory factor analysis, the researcher deduced the initial 5-dimension ILF instrument to 3-dimension ILF. The reduced ILF instrument is preferred to be more fitted instrument to be used in DepEd setting with a variance explained threshold of about $77 \%$ with an inter-item reliability index from 0.913 to 0.938 within components and an all-item internal reliability index of about 0.969 . This study found out that the 3-dimension ILF instrument is valid and reliable in measuring the instructional leadership of our DepEd School administrators. This instrument will give a huge source data for leadership improvement activities across schools and perhaps within our district.
\end{abstract}

Keywords: educational leadership, instructional leadership framework, VMIS, MADIS, Factor Analysis

DOI: $10.7176 / \mathrm{JEP} / 12-21-09$

Publication date:July $31^{\text {st }} 2021$

\section{Introduction}

Educational leadership defines how well an educational institution performs (Vanderlinde et al. 2016). It encompasses the ability to adapt to best practices and implement it seamlessly. Being a leader in an educational setting requires one to take some degree of risk to innovate new system that is expected to bring the institution to a higher status of efficiency in service delivery ("Educational Leadership - Articles, Resources for Educators" n.d.). This study aimed to explore the leadership status of instructional leadership among high school administrators and schoolteachers in two government national high schools - Margarito A. Duavit Memorial National High School (MNHS) and Vicente Madrigal National High School (VMNHS).

The current study mainly wants to establish new constructs using the structured instructional leadership framework that is fully fitted to the responses of the respondents from the two national high school. From five constructs, using all 23 items, the researcher wants to reduce the dimension of the constructs to a lesser number and re-assign the 23 items accordingly to the new reduced constructs.

\subsection{History of MNHS}

The Department of Education - Division of Rizal under the leadership of Schools Division Superintendent, Dr. Edith A. Doblada opened the Vicente Madrigal National High School-Pilapila Annex on October 14, 2002, at Brgy. Pilapila, Binangonan, Rizal. 178 first year students were pulled out from Vicente Madrigal National High School main campus that are residents of Barangay Libid, Libis, Lunsad, Gupiing, Pilapila, Limbon-Limbon, Ithan, Kalinawan and Nagsulo, Cardona, Rizal. The students attended classes at Pilapila Elementary School. It was under the supervision of Mrs. Maria A. Barrameda, Principal of VMNHS with the help of Dr. Trinidad D. Nido, Principal of Pilapila Elementary School. Seven rooms from Pilapila Elementary School functioned as classroom, faculty room and canteen for teachers and students. Classes were handled by the committed and dedicated teachers stationed from the main campus under the supervision of the assigned Officer-In-Charge, Mr. Jonathan P. Esquierdo.

On October 18, 2002, Sangguniang Bayan had convened and come up with the Resolution No. 2002-134 
authorizing Mayor Cesar M. Ynares to negotiate with the owner of a parcel of land located at the boundaries of Brgy. Pilapila and Brgy. Nagsulo, Cardona, Rizal intended for the establishment of a proposed Municipal High School. After series of negotiations, the Provincial Government under the administration of Gov. Rebecca "Nini" A. Ynares began constructing the initial 2-storey building with 10 classrooms in 2003 . It was formally handed to Mr. Jonathan P. Esquierdo on January 30, 2004, on a simple but memorable ceremony. On June 9, 2004, the school transferred to its new home with a lot size of 8,378 square meters and the initial 2-storey Ynares Type building housed the 1,025 first year to third year students with its new Teacher In-Charge, Mr. Celestino A. Santiago. During this year, the Department of Education through the Schools Division Superintendent, Dr. Edith A. Doblada, changed the name of the school from Vicente Madrigal National High School-Pilapila Annex to Margarito A. Duavit Memorial National High School in memory of the late Margarito A. Duavit being the most prominent and outstanding figure of Brgy. Pilapila thus the school gained its independence.

\subsection{History of VMNHS}

The year 1991 was the birth of the time dream of the people of Binangonan, to have a Municipal High School. Then Mayor Casimiro Ynares Jr. contracted Atty. Gilberto Duavit to intercede with the Madrigal Family to donate a parcel of land for the school site, through Atty. Juan Miguel Madrigal Vasquez, 32,458 $\mathrm{m}^{2}$ of land was donated in Quarry Road, Pantok Binangonan, Rizal. Through further negotiations by Mayor Ynares. The Board Members of the Sangguniang Panlalawigan, board member worked hard to pass the resolution approving the sum of ten million $(10,000,000)$ pesos for the two (2) school buildings. It was the time then of Provincial Governor Reynaldo R. San Juan.

The negotiations for the permit to operate a Municipal High School was entrusted to the hands of Mrs. Dionicia A. Villamayor, the District Supervisor of Binangonan 1 by the Schools Division Superintendent Dr. Roxanne A. Salem with the helped of counsellors Mauricio A. Mixto Jr. the Sangguniang Bayan Education Committee Chairman then, some school heads and master teachers, a feasibility study with all the requirements to operate a high school was prepared. The same was submitted to the Department of education Culture and Sports by June 1991.

Through further guidance by the School Division Superintendent, close follows-ups of the permit to operate were done to the region and DECS central office by the District Supervisor and Group of Municipal Officials headed by the Municipal Secretary Pedro San Felipe Jr. and ABC Chairman Felix A. Apostadero it was on September 30, 1991, when the permit to operate first year High School was granted by the DECS. From the day onward, preparation to its formal opening were done through concerned efforts of all municipal officials and the DECS people. On June 15, 1992, with four hundred fifty (450) first year students, ten (10) teachers and four (4) support personnel. VMNHS of Binangonan, Rizal came to reality.

\section{Methodology}

\subsection{Design}

The current study employs a quantitative design which uses an adopted questionnaire checklist. Exploratory factor analysis was executed on the 23 items of the Instructional Learning Framework questionnaire which discusses all about leadership in educational setting (Street et al. 2005; "Instructional Leadership Framework WeTeachNYC" n.d.; California Charter Schools Association 2018).

\subsection{Participant}

54 school administrators and schoolteachers joined to the survey using an adopted questionnaire checklist with 23 items on a 5-point Likert scale. Parallel Analysis (PA) and Exploratory Factor Analysis (EFA) were performed to discover the new factors of instructional leadership framework.

\subsection{Instrumentation}

This study adapted a structure questionnaire checklist for instructional leadership framework which includes 23 item questions in 5 constructs.

This Instructional Leadership Framework (ILF) was developed by the CCSA staff and consultants in 2017. It was designed to be a tool for leaders of new charter schools, outlining strategies to help leaders focus on instructional 
leadership and support strong student outcomes, even as new school leaders struggle with operational challenges. The ILF is not intended to be a definitive source of effective instructional leadership practices, but rather a compilation of key indicators and leader behaviours (California Charter Schools Association 2018).

The ILF was created in conjunction with The Mentor Project, a year-long Federally funded program connecting veteran charter leaders with leaders of newly opened charter schools. Some references within the ILF refer to tools used by participants in The Mentor Project. Beyond those references however, the ILF's domains and indicators can be used outside of a mentoring context by any school leader interested in furthering their school's emphasis on instruction (California Charter Schools Association 2018).

The five constructs are 'Changing Leadership (CL)', 'Culture of Continuous Improvement Leadership (CC)', 'Data Driven Leadership (DD)', 'Curriculum, Instruction and Assessment Leadership (CI)', and 'Equity Leadership (EL)'. CL consists of five items, CC contains four items, DD has three items, CI contains six items and EL has five items. Face and content validity of the adapted questionnaire has been established by the initial proponents with high degree of acceptability.

\subsection{Data Analysis}

Exploratory Factor Analysis was conducted on the initial five constructs (CL, CC, DD, CI, EL) which contain a total of 23 items. Table 1 presented these initial constructs and their respective items and corresponding codes. A cumulative number of 54 school administrators and schoolteachers who are currently employed in the two National High Schools participated in the survey. EFA was executed using 'Principal Axis Factoring' procedure. This methodology is performed to identify the inherited factors in the instrument as assessed by the participating respondents (Yusof et al. 2020). Omission of an item value lower than 0.40 has been enforced a suppression threshold to complement the principal axis factoring procedure.

In addition to EFA, a Confirmatory Factor Analysis was used to determine the maximum likelihood factor for the 23 items of the instructional leadership framework questionnaire and to test the model fit from the collected data. No missing value had been observed that is why there is no need for any data imputation procedure. Any factor loading more than 0.70 were considered as good indicator (Hunzicker 2017; Yusof et al. 2020).

Table 1. Construct of the Instructional Leadership Framework and Items before Exploratory Factor Analysis

\begin{tabular}{|c|c|c|}
\hline Code & Construct & Item \\
\hline A1 & \multirow{5}{*}{$\begin{array}{l}\text { Changing } \\
\text { Leadership } \\
\text { (CL) }\end{array}$} & $\begin{array}{l}\text { Mobilizes a clear and compelling mission and vision that drives academic achievement and important student } \\
\text { outcomes. }\end{array}$ \\
\hline $\mathrm{A} 2$ & & $\begin{array}{l}\text { Maintains action- oriented leadership focused on student achievement that ensures urgent progress towards the } \\
\text { school's goals. }\end{array}$ \\
\hline $\mathrm{A} 3$ & & $\begin{array}{l}\text { Engages in courageous and challenging conversations to keep the learning community focused on what the current } \\
\text { data indicate about student growth and progress to the achieving the mission and vision. }\end{array}$ \\
\hline A4 & & Hold self and staff accountable to maintain high expectations and achieve learning goals. \\
\hline A5 & & Shapes and re- shapes good ideas to build capacity and ownership like participating in strategic planning. \\
\hline B1 & \multirow{4}{*}{$\begin{array}{l}\text { Culture of } \\
\text { Continuous } \\
\text { Improvement } \\
\text { Leadership } \\
\text { (CC) }\end{array}$} & Sustains a focus on a clear set of shared beliefs for the improvement of teaching and learning. \\
\hline $\mathrm{B} 2$ & & Facilitates collaborative studies of pedagogy that result in improved learning for students. \\
\hline B3 & & Engages as the lead learner \\
\hline B4 & & Creates opportunities for shared leadership to continuously improve results. \\
\hline $\mathrm{C} 1$ & \multirow{3}{*}{$\begin{array}{l}\text { Data Driven } \\
\text { Leadership }\end{array}$} & Recognizes and seeks out multiple data sources to direct improvement efforts \\
\hline $\mathrm{C} 2$ & & Assists staff to regularly analyze student work and use data to improve teaching and student learning. \\
\hline $\mathrm{C} 3$ & & Measure impact with specific goals and indicators. \\
\hline D1 & \multirow{6}{*}{$\begin{array}{l}\text { Curriculum, } \\
\text { Instruction and } \\
\text { Assessment } \\
\text { Leadership } \\
\text { (CI) }\end{array}$} & Assists staff in aligning curriculum and assessment to state standards and best instructional practices. \\
\hline D2 & & Base quality teaching and learning on an instructional framework and standards. \\
\hline D3 & & $\begin{array}{l}\text { Clearly communicates, and guides effective instructional practices which lead to continuous improvement of } \\
\text { student outcomes }\end{array}$ \\
\hline D4 & & Provides job- embedded professional development. \\
\hline D5 & & $\begin{array}{l}\text { Monitor instruction and assessment practices through classroom observations and rigorous, timely \& focused } \\
\text { feedback. }\end{array}$ \\
\hline D6 & & Evaluates staff in use of effective instruction and assessment practices. \\
\hline E1 & \multirow{5}{*}{$\begin{array}{l}\text { Equity } \\
\text { Leadership } \\
\text { (EL) }\end{array}$} & Acknowledges and owns the achievement gap for all subgroups. \\
\hline E2 & & Identifies barriers to achievement and seeks help in closing the gap. \\
\hline E3 & & Demonstrates a commitment to closing the achievement gap. \\
\hline E4 & & Ensures the entire school community urgently addresses inequities in student achievement. \\
\hline E5 & & Sustains a comprehensive tiered intervention system \\
\hline
\end{tabular}




\section{Results}

We start our analysis with the EFA result on the Instructional Leadership Framework instrument. Table 2 below provides the Kaiser-Meyer-Olking (KMO) sample adequacy test 0.61 and Barlett's Tet of Sphericity with $\left(\chi^{2}(253)\right.$ $=1,777.15, \mathrm{p}<0.001)$. The results provide proof of the adequacy of the small sample for the purpose of EFA and CFA (Uribe-Flórez, Al-Rawashdeh, and Morales 2014; Yusof et al. 2020).

Table 2. KMO and Bartlett's Test Scores

\begin{tabular}{ccc}
\hline \multicolumn{2}{c}{ Kaiser-Meyer-Olkin Measure of Sampling Adequacy. } & .606 \\
\hline Bartlett's Test of Sphericity & Approx. Chi-Square & 1777.145 \\
& df & 253 \\
& Sig. & .000 \\
\hline
\end{tabular}

To determine the inherited factors in the Instructional Leadership Framework instrument, the orthogonal rotation with varimax method was employed. This ensures that the observes variables given by the items are not correlated with each other. We will have a threshold of at least $60 \%$ variance explained or greater to set the cut off number of components (Hunzicker 2017; Yusof et al. 2020; Uribe-Flórez, Al-Rawashdeh, and Morales 2014). In addition, the eigenvalues bigger than 1 were initially considered. Based on the results of Table 3 , there are only three dimensions necessary to define the ILF instrument based on the procedure of EFA. The total variance explained is $77.281 \%$ way beyond our threshold of at least $60 \%$. The three components as well have initial eigenvalues from 1.360 to 14.908. Figure 1 supports the sufficiency of 2-3 components ILF instrument as the elbow signal from the plot suggests.

Table 3. Total Variance Explained

\begin{tabular}{|c|c|c|c|c|c|c|c|c|c|}
\hline \multirow{2}{*}{ Component } & \multicolumn{3}{|c|}{ Initial Eigenvalues } & \multicolumn{3}{|c|}{ Extraction Sums of Squared Loadings } & \multicolumn{3}{|c|}{ Rotation Sums of Squared Loadings } \\
\hline & Total & $\%$ of Variance & Cumulative \% & Total & $\%$ of Variance & Cumulative \% & Total & $\%$ of Variance & Cumulative \% \\
\hline 1 & 14.908 & 64.817 & 64.817 & 14.655 & 63.715 & 63.715 & 6.210 & 27.000 & 27.000 \\
\hline 2 & 1.507 & 6.550 & 71.368 & 1.307 & 5.684 & 69.400 & 6.023 & 26.185 & 53.185 \\
\hline 3 & 1.360 & 5.913 & 77.281 & 1.110 & 4.824 & 74.224 & 4.839 & 21.039 & 74.224 \\
\hline
\end{tabular}

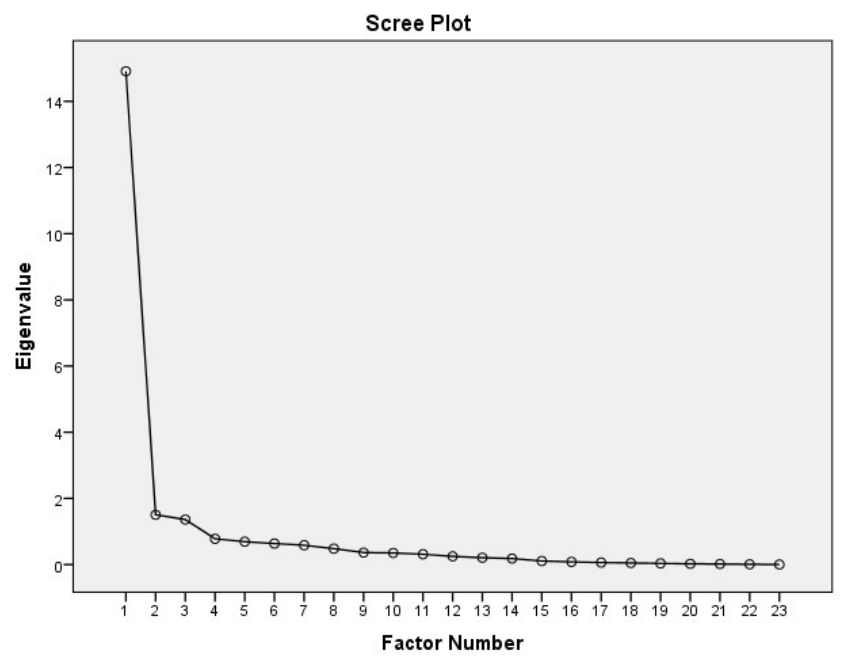

Figure 1. Scree Plot 
After the EFA procedure, only three dimensions of the ILF instrument were formed. It deviates to the original 5dimension ILF instrument. Based on the result from Table 4, we can see factor loadings of at least 0.40 was retained, else, the item will be dropped. According to the result, there were no items with factor loading lesser than 0.40.

Table 4. Rotated Factor Matrix showing the Components and Corresponding Items

\begin{tabular}{|c|c|c|c|}
\hline \multirow{2}{*}{ Items } & \multicolumn{3}{|c|}{ Components } \\
\hline & 1 & 2 & 3 \\
\hline B2 & .746 & & \\
\hline B3 & .714 & & \\
\hline D1 & .704 & & \\
\hline D2 & .741 & & \\
\hline D3 & .736 & & \\
\hline D4 & .585 & & \\
\hline D5 & .720 & & \\
\hline D6 & .805 & & \\
\hline $\mathrm{A} 1$ & & .620 & \\
\hline A2 & & .848 & \\
\hline $\mathrm{A} 3$ & & .608 & \\
\hline A4 & & .660 & \\
\hline A5 & & .648 & \\
\hline B1 & & .630 & \\
\hline B4 & & .526 & \\
\hline $\mathrm{C} 1$ & & .715 & \\
\hline $\mathrm{C} 2$ & & .610 & \\
\hline $\mathrm{C} 3$ & & .650 & \\
\hline E1 & & & .738 \\
\hline E2 & & & .710 \\
\hline E3 & & & .878 \\
\hline E4 & & & .800 \\
\hline E5 & & & .664 \\
\hline
\end{tabular}

*Extraction Method: Principal Axis Factoring; Rotational Method: Varimax with Kaiser Normalization; Convergence in 7 iterations

Internal consistency or internal reliability for each new construct was calculated using Cronbach's Alpha coefficient. A threshold of 0.90 is exercise in literature as valid and acceptable internal reliability coefficient for an instrument with a minimum coefficient of about 0.70 . Table 5 provides the Cronbach's Alpha for each of the new component. It can be gleaned that all items or components are highly reliable and valid since all were beyond 0.90 threshold.

Table 5. Internal consistency of each Constructs

\begin{tabular}{ccc}
\hline Component & Number of items & Cronbach's Alpha \\
\hline 1 & 8 & 0.960 \\
2 & 10 & 0.951 \\
3 & 5 & 0.948 \\
All & 23 & 0.975 \\
\hline
\end{tabular}

Table 6 provides the re-alignment of the items to the new construct - CI, DD, EL. The previously given 5dimension not as fit as the new 3-dimension ILF instrument when used to the DepEd respondents. We can clearly see that our component 1, CI, has 8 items, component, DD has 10 items, and component 3, EL, has 5 items for a total of 23-item ILF instrument. 
Table 6. New Construct and Respective Items after Exploratory Factor Analysis

\begin{tabular}{|c|c|c|}
\hline Item & $\begin{array}{c}\text { Initial } \\
\text { Construct }\end{array}$ & $\begin{array}{c}\text { New } \\
\text { Construct }\end{array}$ \\
\hline $\begin{array}{l}\text { Facilitates collaborative studies of pedagogy that result in improved learning for } \\
\text { students. }\end{array}$ & $\mathrm{CC}$ & \multirow{8}{*}{$\begin{array}{l}\text { Curriculum, } \\
\text { Instruction and } \\
\text { Assessment } \\
\text { Leadership } \\
\text { (CI) }\end{array}$} \\
\hline Engages as the lead learner & $\mathrm{CC}$ & \\
\hline $\begin{array}{l}\text { Assists staff in aligning curriculum and assessment to state standards and best } \\
\text { instructional practices. }\end{array}$ & $\mathrm{CI}$ & \\
\hline Base quality teaching and learning on an instructional framework and standards. & $\mathrm{CI}$ & \\
\hline $\begin{array}{l}\text { Clearly communicates, and guides effective instructional practices which lead to } \\
\text { continuous improvement of student outcomes }\end{array}$ & $\mathrm{CI}$ & \\
\hline Provides job- embedded professional development. & $\mathrm{CI}$ & \\
\hline $\begin{array}{l}\text { Monitor instruction and assessment practices through classroom observations and } \\
\text { rigorous, timely \& focused feedback. }\end{array}$ & $\mathrm{CI}$ & \\
\hline Evaluates staff in use of effective instruction and assessment practices. & $\mathrm{CI}$ & \\
\hline $\begin{array}{l}\text { Mobilizes a clear and compelling mission and vision that drives academic } \\
\text { achievement and important student outcomes. }\end{array}$ & $\mathrm{CL}$ & \multirow{10}{*}{$\begin{array}{l}\text { Data Driven } \\
\text { Changes } \\
\text { Leadership } \\
\text { (DD) }\end{array}$} \\
\hline $\begin{array}{l}\text { Maintains action- oriented leadership focused on student achievement that ensures } \\
\text { urgent progress towards the school's goals. }\end{array}$ & $\mathrm{CL}$ & \\
\hline $\begin{array}{l}\text { Engages in courageous and challenging conversations to keep the learning } \\
\text { community focused on what the current data indicate about student growth and }\end{array}$ & $\mathrm{CL}$ & \\
\hline $\begin{array}{l}\text { progress to the achieving the mission and vision. } \\
\text { Hold self and staff accountable to maintain high expectations and achieve learning } \\
\text { goals. }\end{array}$ & $\mathrm{CL}$ & \\
\hline $\begin{array}{l}\text { Shapes and re-shapes good ideas to build capacity and ownership like participating } \\
\text { in strategic planning. }\end{array}$ & $\mathrm{CL}$ & \\
\hline $\begin{array}{l}\text { Sustains a focus on a clear set of shared beliefs for the improvement of teaching and } \\
\text { learning. }\end{array}$ & $\mathrm{CC}$ & \\
\hline Creates opportunities for shared leadership to continuously improve results. & $\mathrm{CC}$ & \\
\hline Recognizes and seeks out multiple data sources to direct improvement efforts & $\mathrm{DD}$ & \\
\hline $\begin{array}{l}\text { Assists staff to regularly analyze student work and use data to improve teaching and } \\
\text { student learning. }\end{array}$ & $\mathrm{DD}$ & \\
\hline Measure impact with specific goals and indicators. & $\mathrm{DD}$ & \\
\hline Acknowledges and owns the achievement gap for all subgroups. & EL & \multirow{5}{*}{$\begin{array}{c}\text { Equity } \\
\text { Leadership } \\
\text { (EL) }\end{array}$} \\
\hline Identifies barriers to achievement and seeks help in closing the gap. & EL & \\
\hline Demonstrates a commitment to closing the achievement gap. & EL & \\
\hline $\begin{array}{l}\text { Ensures the entire school community urgently addresses inequities in student } \\
\text { achievement. }\end{array}$ & EL & \\
\hline Sustains a comprehensive tiered intervention system & EL & \\
\hline
\end{tabular}

Figure 2 on the other hand, provides the factor loadings of each item in the new construct. The factor loading ranges from 0.75 to 0.93 . 


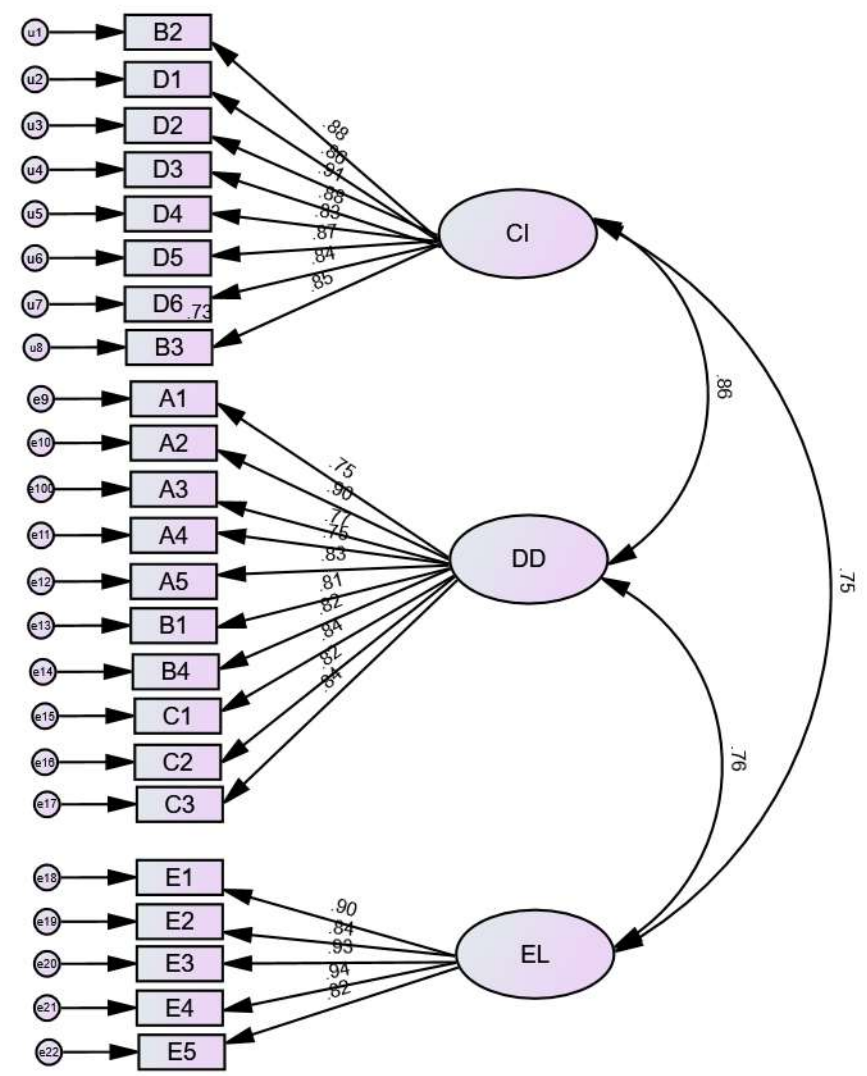

Figure 2. Initial Confirmatory Factor Analysis of Instructional Leadership Framework

\section{Analysis and Discussion}

The result of this study provided that the 5-dimension ILF instrument can be reduced to a fitted model that contain only 3-dimensions after executing EFA and CFA. All 23 items were included in the final model none were dropped. The new ILF instrument is expected to be more appropriate to be used in DepEd. This instrument will ensure that every school has the plan and tools to continuously improve instruction and provide our students with the rigorous learning experiences they all deserve and take stock to identify what instruction every student is receiving, how they're receiving it, why they're receiving it, and how it can be improved (Street et al. 2005; California Charter Schools Association 2018).

\section{References}

California Charter Schools Association (2018). "Instructional Leadership Framework (ILF)."

"Educational Leadership - Articles, Resources for Educators." n.d., 12. Accessed June 13, 2021. http://www.ascd.org/publications/educational-leadership.aspx

Hunzicker, Jana (2017). "From Teacher-to-Teacher Leader: A Conceptual Model." International Journal of Teacher Leadership 8 (2): 1-27.

"Instructional Leadership Framework WeTeachNYC." n.d. Accessed June 13, 2021. https://www.weteachnyc.org/approach/instructional-leadership-framework/.

Street, et.al. (2005). "Maryland State Department of Education Maryland State Board of Education," no. October. Uribe-Flórez, et. al. (2014). "Perceptions about Teacher Leadership: Do Teacher Leaders and Administrators Share a Common Ground?” Journal of International Education and Leadership 4 (1). http://www.jielusa.org/.

Vanderlinde, et. al. (2016). "Professional Learning of Teacher Educators, Teachers, and Student Teachers."

Yusof, et. al. (2020). "Exploratory and Confirmatory Factor Analysis on the Values Aspects of Teacher Leadership Model." Universal Journal of Educational Research 8 (12): 7085-7100. https://doi.org/10.13189/ujer.2020.081276 